OPEN ACCESS

Edited by:

Arumugam Muthu,

Council of Scientific and

Industrial Research, India

Reviewed by:

Wenjie Liao,

Sichuan University, China

Sachin Kumar,

Sardar Swaran Singh National Institute of Renewable Energy, India

*Correspondence:

Qusai Al Abdallah qalabdal@uthsc.edu

Specialty section: This article was submitted to Bioenergy and Biofuels, a section of the journal Frontiers in Energy Research

Received: 12 August 2016 Accepted: 17 October 2016

Published: 04 November 2016

Citation:

Al Abdallah Q, Nixon BT and Fortwendel JR (2016) The Enzymatic

Conversion of Major Algal and

Cyanobacterial Carbohydrates to Bioethanol.

Front. Energy Res. 4:36. doi: 10.3389/fenrg.2016.00036

\section{The Enzymatic Conversion of Major Algal and Cyanobacterial Carbohydrates to Bioethanol}

\author{
Qusai Al Abdallah ${ }^{1 *}$, B. Tracy Nixon ${ }^{2}$ and Jarrod R. Fortwendel ${ }^{1}$ \\ ${ }^{1}$ Department of Clinical Pharmacy, University of Tennessee Health Science Center, Memphis, TN, USA, ${ }^{2}$ Department of \\ Biochemistry and Molecular Biology, The Pennsylvania State University, University Park, PA, USA
}

The production of fuels from biomass is categorized as first-, second-, or thirdgeneration depending upon the source of raw materials, either food crops, lignocellulosic material, or algal biomass, respectively. Thus far, the emphasis has been on using food crops creating several environmental problems. To overcome these problems, there is a shift toward bioenergy production from non-food sources. Algae, which store high amounts of carbohydrates, are a potential producer of raw materials for sustainable production of bioethanol. Algae store their carbohydrates in the form of food storage sugars and structural material. In general, algal food storage polysaccharides are composed of glucose subunits; however, they vary in the glycosidic bond that links the glucose molecules. In starch-type polysaccharides (starch, floridean starch, and glycogen), the glucose subunits are linked together by $\alpha-(1 \rightarrow 4)$ and $\alpha-(1 \rightarrow 6)$ glycosidic bonds. Laminarin-type polysaccharides (laminarin, chrysolaminarin, and paramylon) are made of glucose subunits that are linked together by $\beta-(1 \rightarrow 3)$ and $\beta-(1 \rightarrow 6)$ glycosidic bonds. In contrast to food storage polysaccharides, structural polysaccharides vary in composition and glycosidic bond. The industrial production of bioethanol from algae requires efficient hydrolysis and fermentation of different algal sugars. However, the hydrolysis of algal polysaccharides employs more enzymatic mixes in comparison to terrestrial plants. Similarly, algal fermentable sugars display more diversity than plants, and therefore more metabolic pathways are required to produce ethanol from these sugars. In general, the fermentation of glucose, galactose, and glucose isomers is carried out by wild-type strains of Saccharomyces cerevisiae and Zymomonas mobilis. In these strains, glucose enters glycolysis, where is it converted to pyruvate through either Embden-Meyerhof-Parnas pathway or Entner-Doudoroff pathway. Other monosaccharides must be converted to fermentable sugars before entering glycolysis. In contrast, microbial wild-type strains are not capable of producing ethanol from alginate, and therefore the production of bioethanol from alginate was achieved by using genetically engineered microbial strains, which can simultaneously hydrolyze and ferment alginate to ethanol. In this review, we emphasize the enzymatic hydrolysis processes of different algal polysaccharides. Additionally, we highlight the major metabolic pathways that are employed to ferment different algal monosaccharides to ethanol.

Keywords: bioethanol, algal carbohydrates, food reserves, structural polysaccharides, enzymatic hydrolysis, fermentation 


\section{INTRODUCTION}

During the last decade, growing concerns over depleting fossil oil reserves and increasing greenhouse gas emissions have led to the use of food crops as biomass for making what is called firstgeneration biofuel. Nevertheless, expansion in biofuel production from food crops has drawn attention to several environmental impacts, such as the conversion of agricultural land from producing food crops to producing biofuel crops and the deforestation of hundreds of thousands of acres (Groom et al., 2008; Searchinger et al., 2008; Naik et al., 2010).

To overcome these environmental problems, there is a shift toward the production of biofuel from non-food biomass sources, such as lignocellulosic and algal biomass sources, which are also known as the second- and third-generation biofuel crops, respectively (Badger, 2002; Zheng et al., 2009; Brennan and Owende, 2010). However, commercial production of second-generation biofuels is only limited to countries with large agricultural and forestry lands. Therefore, algal biomass is an emerging alternative for the production of biofuels.

The production of biofuel from algae has several advantages over the first- and second-generation of biomass sources [discussed by John et al. (2011)]. First, algae serve as non-food feedstock, which does not compromise our food security. Second, algae grow in aquatic habitats and thereby do not compete with food crops on agricultural land, or cause deforestation. Third, algal biomass can be used to produce two types of biofuel (bioethanol and biodiesel) since they accumulate high amounts of carbohydrates and lipids. Finally, the fresh water requirement for algal growth is significantly lower than plant demands to produce the same volume of biofuel. Nevertheless, there are several constraints that restrict the production of biofuel from algae [discussed by Hannon et al. (2010), Singh et al. (2011), and Behera et al. (2015)].

The hydrolysis of algal carbohydrates to basic sugars is primarily carried out using chemical and enzymatic methods. Although the chemical method yields high concentrations of fermentable sugars in a short time, this method requires harsh reaction conditions producing byproducts, which might inhibit the fermentation process and require costly disposal processes. In contrast, enzymatic hydrolysis produces high amounts of fermentable sugars under mild conditions without producing inhibitory byproducts (Chen et al., 2013).

Algae produce a wide spectrum of polysaccharides that are specific to an algal group, family, or species. The enzymatic hydrolysis of algal polysaccharides requires a wider range of enzymatic mixtures, compared to plants. This review focuses on the enzymatic hydrolysis steps of the major algal carbohydrates and their fermentation process to ethanol. Since the scope of this topic is broad, only the fundamental concepts of the field are addressed in this review. Nevertheless, we will refer the reader to other reviews that are complementary to this topic.

\section{THIRD-GENERATION BIOFUELS FROM ALGAL BIOMASS}

Algae are photosynthetic eukaryotes that are distinguishable from cyanobacteria, which are photosynthetic prokaryotes (Brodie and
Lewis, 2007). Because of their importance for biofuel production, this review will cover cyanobacteria as well.

Algae vary dramatically in size and morphology from microscopic unicellular phytoplanktons to 50-m long seaweeds. Based on their morphology and size, algae are classified into microalgae and macroalgae. Currently, microalgae are the major source for third-generation biofuels. In contrast, only small amount of cyanobacterial biomass are utilized for bioethanol production. Additionally, development of methods that overcome obstacles in using macroalgae would greatly improve harvesting bioethanol from natural, renewable biomaterials. The advantages and disadvantages of relevant algal sources are summarized in Table 1 .

\section{Microalgae Are the Current Source for Third-generation Biofuels}

Microalgae are microscopic in size (measured in micrometers) and exist as single cells; or unspecialized multicellular filaments and colonies (Satyanarayana et al., 2011). They are highly diverse including 40,000 species that belong to nearly all major algal groups with the exception of brown algae [reviewed by Metting (1996), Dahiya (2015), and Kim (2015)].

Microalgae exhibit several features that favor using them for industrial production of biofuel. First, they lack specialized tissues and structures, which simplify the cultivation and harvesting processes. In addition, microalgae exhibit high rates of asexual growth and yield huge amount of biomass from low inoculum (Packer, 2009; Chen et al., 2010). Furthermore, microalgae accumulate large amounts of polysaccharides and triacylglycerols storage lipids and energy sources, and thereby they are suitable for simultaneous production of bioethanol and biodiesel (Mata et al., 2010; Singh et al., 2011; Suutari et al., 2015).

The commercial production of microalgal biomass is obtained from cultivating the freshwater algae Chlorella and Haematococcus, and marine algae, such as Dunaliella, Phaeodactylum, and Tetraselmis (Lee, 1997; Wikfors and Ohno, 2001; Carlsson et al., 2007; Benemann, 2013; Borowitzka, 2013). Additionally, other microalgae have been shown to be a potential source for third-generation biofuels due to their high oil and carbohydrates contents (Singh et al., 2011).

One of the challenges for commercial cultivation of microalgae is the economic feasibility. In their marine natural habitats, the productivity of microalgae is very low, not exceeding $10 \%$ of that for macroalgae under the same conditions. Such low yield of microalgal biomass is not sufficient for the industrial production of bioethanol. To improve the yield, microalgae should be cultivated in artificial systems (Lüning and Pang, 2003). The most common two methods for the cultivation of microalgae are the outdoor open pond system and the closed photobioreactor [for reviews, refer to Brennan and Owende (2010) and Benemann (2013)]. The photobioreactor system, which produces high biomass under controlled growth conditions, requires high capital and operating costs (Pruvost et al., 2016). In contrast, cultivation of microalgae in open ponds involves lower capital and operating costs but offers low productivity. Additionally, microalgal cultures growing in open ponds are exposed to contaminants and affected by seasonal variations (Chisti, 2016). In both systems, microalgal density must be controlled to maintain a viable culture (Wang et al., 2009). Other challenges associated with biofuel from 
TABLE 1 | Comparison between relevant algal sources and the advantages and disadvantages of employing each for the production of third-generation biofuels.

\begin{tabular}{|c|c|c|c|}
\hline Algal source & Characteristics & $\begin{array}{l}\text { Current industrial } \\
\text { applications }\end{array}$ & Advantages and disadvantages \\
\hline Microalgae & $\begin{array}{l}\text { (1) Eukaryote } \\
\text { (2) Microscopic }\end{array}$ & $\begin{array}{l}\text { (1) The major source } \\
\text { for third-generation } \\
\text { biofuels. } \\
\text { (2) A major source for } \\
\text { several nutritional } \\
\text { and pharmaceutical } \\
\text { products. }\end{array}$ & $\begin{array}{l}\text { Advantages: } \\
\text { (1) Easy to cultivate and harvest. } \\
\text { (2) High growth rates in artificial growth systems. } \\
\text { (3) Suitable for simultaneous production of bioethanol and biodiesel. } \\
\text { Disadvantages: } \\
\text { (1) Several microalgae that are employed for biofuel production require freshwater for growth. } \\
\text { (2) Low productivity levels in their marine natural habitats, therefore microalgae should be } \\
\text { cultivated in artificial systems, which involve capital and operating costs. } \\
\text { (3) Microalgae that are cultivated in open ponds are normally cultured outdoors, and thus } \\
\text { biomass production is heavily affected by contamination with epiphytes, microbial infections, } \\
\text { and seasonal variations. }\end{array}$ \\
\hline Cyanobacteria & $\begin{array}{l}\text { (1) Prokaryote } \\
\text { (2) Microscopic }\end{array}$ & $\begin{array}{l}\text { (1) A minor source for } \\
\text { third-generation } \\
\text { biofuels. } \\
\text { (2) A major source for } \\
\text { several nutritional } \\
\text { and pharmaceutical } \\
\text { products. }\end{array}$ & $\begin{array}{l}\text { Advantages: } \\
\text { (1) Easy to cultivate and harvest. } \\
\text { (2) The simple nutrient requirements of cyanobacteria make its cultivation and harvesting simple } \\
\text { and inexpensive. } \\
\text { (3) Higher photosynthetic levels and growth rates than algae and plants (only if light is provided } \\
\text { in saturating amounts). } \\
\text { Disadvantages: } \\
\text { (1) Cyanobacteria are not suitable for biodiesel production. } \\
\text { (2) Accumulate significantly lower amounts of carbohydrates (\% of dry weight) than microalgae. } \\
\text { (3) Saturating amounts of light must be provided to reach highest photosynthesis rates from } \\
\text { cyanobacteria. }\end{array}$ \\
\hline Macroalgae & $\begin{array}{l}\text { (1) Eukaryote } \\
\text { (2) Macroscopic }\end{array}$ & $\begin{array}{l}\text { (1) A major source for } \\
\text { several nutritional } \\
\text { and pharmaceutical } \\
\text { products. }\end{array}$ & $\begin{array}{l}\text { Advantages: } \\
\text { (1) Macroalgae produce more biomass in their marine natural habitats and therefore do not } \\
\text { require cultivation in costly artificial systems. } \\
\text { (2) Does not require freshwater for cultivation. } \\
\text { (3) Significantly higher annual biomass production for non-biofuel industrial purposes. This } \\
\text { carbohydrate-rich biomass can be employed for biofuel production purposes as well. } \\
\text { Disadvantages: } \\
\text { (1) Macroalgae are not suitable for the production of biodiesel. } \\
\text { (2) The production is heavily affected by contaminants and seasonal variations. } \\
\text { (3) To achieve the commercial levels of bioethanol from macroalgae, glucose-, and non- } \\
\text { glucose-based sugars must be fermented. }\end{array}$ \\
\hline
\end{tabular}

microalgae have been discussed in detail elsewhere (Hannon et al., 2010; Benemann, 2013; Scaife et al., 2015).

\section{Macroalgae Are an Unexploited Potential Source for Bioethanol}

Macroalgae refer to the macroscopic seaweeds. They are characterized by forming multicellular specialized tissues and defined structures that are comparable to plant leaves and roots (John and Anisha, 2012; Murphy et al., 2013). Macroalgae are less versatile than microalgae and are distributed primarily over green, red, and brown algae (Jung et al., 2013). In comparison to terrestrial plants, macroalgae grow faster and produce more biomass per area due to their high photosynthetic efficiency (Murphy et al., 2013; Yanagisawa et al., 2013).

Although commercial third-generation biofuels are derived from microalgal biomass, seaweeds (specifically red and brown macroalgae) serve as an unexploited potential source for bioethanol production due to two facts. First, macroalgae combine high biomass productivity with low capital and operating costs owing to the fact that macroalgae are harvested from naturally occurring stocks or aquacultured sea farms. Such cultivation systems require capital and operating costs that are significantly lower than the microalgal open ponds, nevertheless they provide high biomass productivity (Carlsson et al., 2007; Bruton et al., 2009; Jung et al., 2013; Yanagisawa et al., 2013; Rajkumar et al., 2014). Second, macroalgae are cultivated worldwide on a large scale for non-biofuel purposes. The remainder of the biomass, which is rich in carbohydrates, can be hydrolyzed to produce ethanol. In fact, the worldwide biomass production from macroalgae greatly surpasses that of microalgae. For example, in 2010, approximately 9 million and 6.75 million wet metric tons (WMT) were harvested from red and brown macroalgae, respectively (Jung et al., 2013). In comparison, a total of only 6.2 thousand dry metric tons (DMT) were produced by major microalgal species, such as Chlorella sp., Dunaliella salina, and Haematococcus pluvialis, in the same year [refer to Table 2 in Jung et al. (2013)]. Additionally, $93 \%$ of the worldwide cultivated macroalgal biomass is produced from only four genera that belong to the brown algae (Laminaria $65.8 \%$ and Undaria 9.8\%) and red algae (Porphyra 12.6\% and Gracilaria 4.8\%) (Zemke-White and 
Ohno, 1999). The potential application of macroalgae for biofuel production has been reviewed by others (Murphy et al., 2013).

The production of biofuels from macroalgae has several environmental advantages [discussed by Hughes et al. (2012)] and is challenged by several obstacles, which will be discussed here. First, in contrast to microalgal feedstocks, which are used for simultaneous production of bioethanol and biodiesel, macroalgae accumulate considerable amounts of carbohydrates, and thus can be used to produce bioethanol only [see Table 1 in Singh et al. (2011); Tables 1 and 2 in Suutari et al. (2015)]. Second, macroalgae are normally cultured outdoors, and thus biomass production is heavily affected by contamination with epiphytes (Lüning and Pang, 2003) and microbial infections (Ramaiah, 2006). Third, the macroalgal carbohydrates content varies depending on the alga growth stage and seasonal variations (Suutari et al., 2015). Fourth, macroalgae accumulate lower amounts of glucan food reserves (i.e., glucose-based polysaccharides) in comparison to microalgae, while producing high amounts of non-glucose-based sugars, such as mannitol and cell wall polysaccharides. Therefore, the industrial production of bioethanol from macroalgae requires fermentation of both glucose- and non-glucose-based sugars (Yanagisawa et al., 2013).

\section{Cyanobacteria Serve as a Minor Source for Third-generation Bioethanol}

Spirulina sp. is the most commonly grown cyanobacterium for commercial use. Its biomass is used primarily for human and animal consumption; however, only a small portion is directed toward biofuel production (Ciferri, 1983; Wikfors and Ohno, 2001; Habib et al., 2008; Benemann, 2013). Additionally, several cyanobacterial strains of Synechococcus species have been genetically modified for enhanced commercial production of bioethanol [reviewed by Dexter et al. (2015)].

The production of biofuel from cyanobacteria has several advantages [discussed by Quintana et al. (2011) and Sarsekeyeva et al. (2015)]. Among these advantages is the fact that many cyanobacteria, e.g., Spirulina and Synechococcus, accumulate high amounts of glycogen, which can be easily extracted and fermented to ethanol (See Conversion of Glycogen to Glucose). However, there are several disadvantages of using cyanobacterial biomass for biofuel production. For example, in contrast to microalgae, which store high amounts of lipids and carbohydrates, cyanobacteria do not accumulate significant amounts of lipids, and therefore they are not suitable for biodiesel production (Quintana et al., 2011). Other challenges that constrain bioethanol production from cyanobacteria have been discussed by other reports (Nozzi et al., 2013).

\section{THE MAJOR ALGAL POLYSACCHARIDES}

Similar to plants, photosynthesis in algae is divided into two steps: the light-dependent reactions and Calvin cycle. In the light-dependent reactions, light energy is absorbed at the thylakoid membranes in the chloroplasts, where it is converted into adenosine triphosphate (ATP) and the reduced form of nicotinamide-adenine dinucleotide phosphate (NADPH). The energy molecules NADPH and ATP are then employed by Calvin cycle to metabolize carbon dioxide and water into sugar [see Figure 1 in Moroney and Ynalvez (2001)]. For reviews on algal photosynthesis, we recommend the reader to refer to Moroney and Ynalvez (2001).

Algae produce a wide range of polysaccharides depending on the algal species (Table 2). This diverse collection of polysaccharides functions primarily as food reserves or structural material (Figure 1). Here, we describe the most economically important algal sugars, which have received considerable amount of research interest. The advantages and disadvantages of employing these sugars for bioethanol production are highlighted in Table 3. For more information about algal polysaccharides, we refer the reader to previously published reviews (Peat and Turvey, 1965; Percival, 1970, 1979; Avigad and Dey, 1997; Grant Reid, 1997; Synytsya et al., 2015).

Food reserves are easily fermented into ethanol and thus are the primary source for industrial third-generation bioethanol. In contrast, the hydrolysis of structural carbohydrates is challenging due to their rigidity. Therefore, optimization of the hydrolysis process of structural carbohydrates carries the promise of maximizing ethanol yield. In this section, we will first review the major algal food reserves. Additionally, we will discuss major algal structural polysaccharides because of their potential in enhancing the yield of bioethanol from algal feedstock.

\section{Food Reserves}

The majority of algae store their food reserves in the form of starch-type polysaccharides (such as starch, floridean starch, and glycogen) (Viola et al., 2001; Deschamps et al., 2008; Quintana et al., 2011) or laminarin-type polysaccharides (such as chrysolaminarin and laminarin) (Michel et al., 2010). Additionally, brown algae accumulate large amounts of mannitol, which functions as an antioxidant and regulator of cell osmolarity (Davis et al., 2003; Iwamoto and Shiraiwa, 2005).

Starch is a homopolysaccharide of glucose units that are linked by $\alpha-(1 \rightarrow 4)$ glycosidic bonds to form a linear amylose; and via $\alpha-(1 \rightarrow 6)$ bonds to form amylopectin (Table 2) (Fengel and Gert, 1989; Busi et al., 2014). In contrast to plants, which store starch granules in the amyloplast, most algae lack the amyloplast, and therefore store starch grains in the chloroplast (Busi et al., 2014). Exceptions to this are the red algae, Dinophyta (Dinoflagellates), and Glaucophyta, which store their food reserves in the cytosol (Radakovits et al., 2010). Several algal species have been reported to store relatively high concentrations of starch, reaching in some species to about $50 \%$ of the dry weight [see Table 1 in John et al. (2011)].

Floridean starch is another main food reserve polysaccharide (Table 2). It is a starch derivative that is synthesized by red algae (Rhodophyta). Its granules differ from starch by lacking amylose and thereby are composed completely of amylopectin (Viola et al., 2001). The red alga Seirospora griffithsiana stores up to $80 \%$ of its cell volume as floridean starch. The granules are similar in structure to plant starch but more variable in size (diameter: 0.3-1.7 $\mu \mathrm{m}$ ) and shape (Sheath et al., 1981).

Laminarin and chrysolaminarin are the third major food reserves. They are linear polymers of $\beta-(1 \rightarrow 3)$ glucan repeating units with $\beta-(1 \rightarrow 6)$ branches in the ratio of $15: 1$ for laminarin 
TABLE 2 | Chemical structure and distribution of food reserves and structural polysaccharides among different groups of algae.

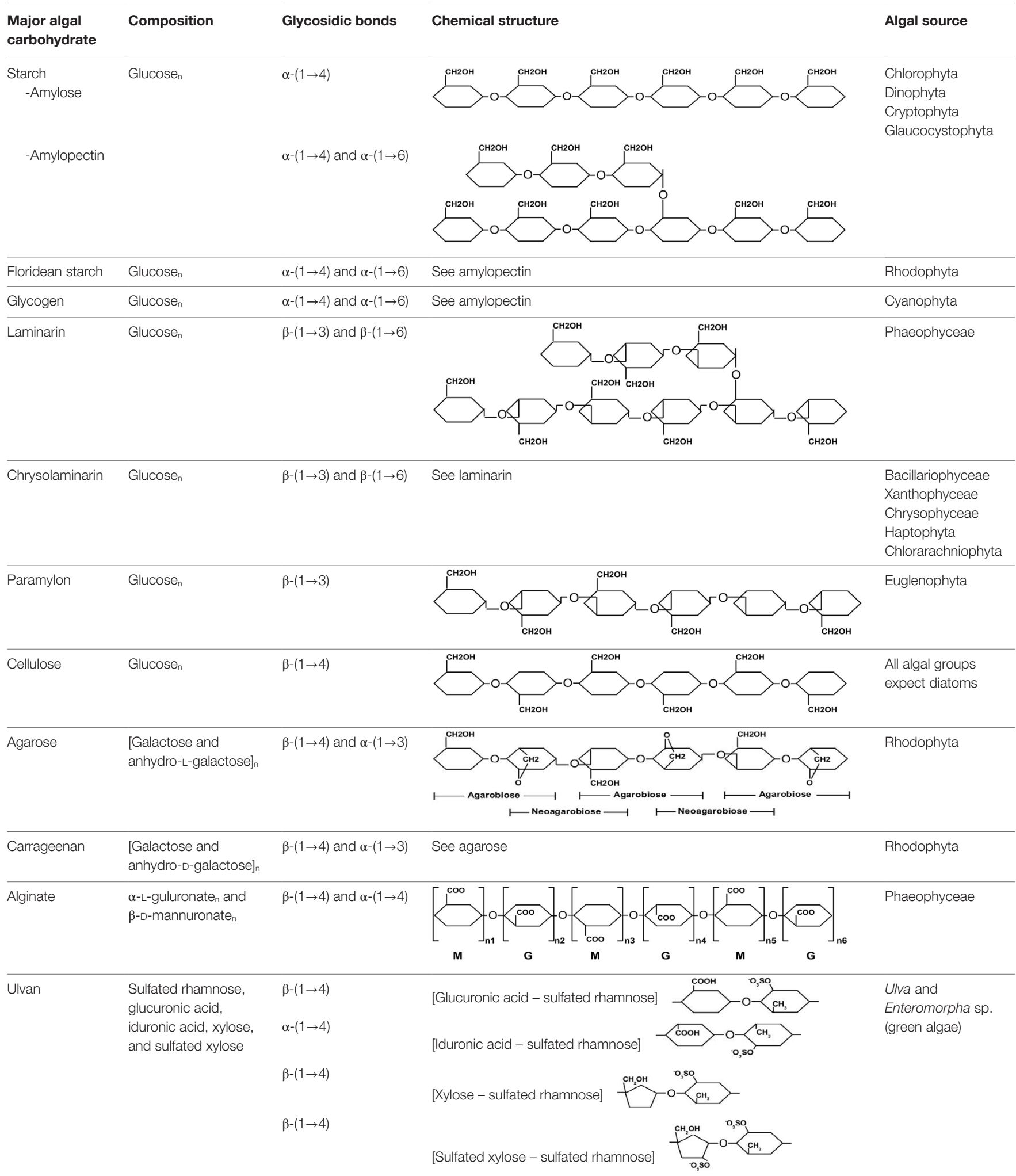

Fucoidan Sulfated L-fucose $\mathrm{n}_{\mathrm{\alpha}-(1 \rightarrow 2)} \begin{aligned} & \text { Predominantly } \\ & \alpha, \mathrm{so}\end{aligned}$

$n$ is the number of repeating units of the molecule.

$M, \beta$-D-mannuronate.

G, $\alpha$-L-guluronaten. 


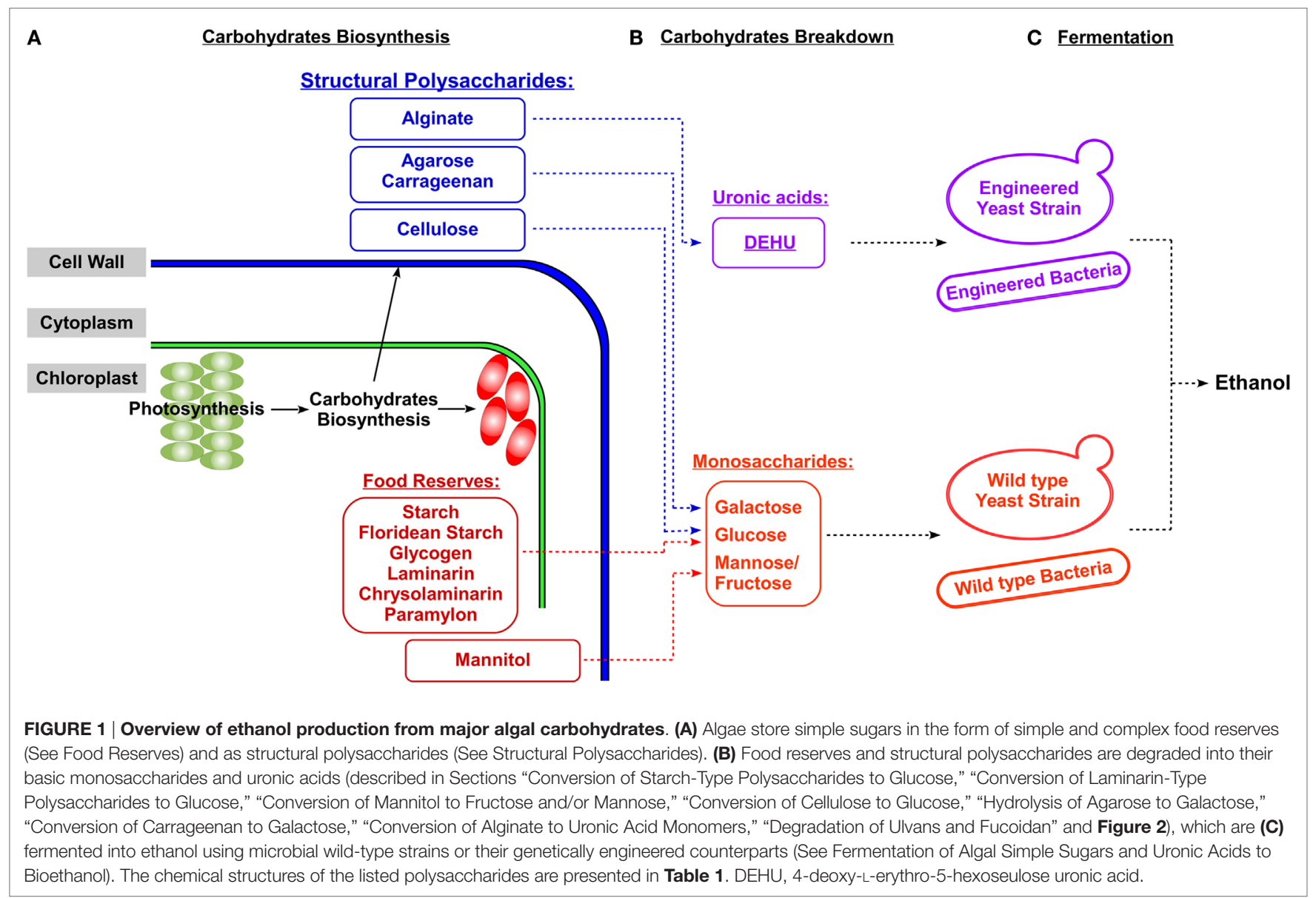

and 11:1 for chrysolaminarin (Table 2) (Beattie et al., 1961; Michel et al., 2010). Laminarin is synthesized by brown algae, and it forms either a G-chain - with glucose molecule at the reducing end - or an $\mathrm{M}$-chain - with mannitol at the reducing end (Kadam et al., 2015; Motone et al., 2016). Accumulation of high amounts of laminarin in algae has been reported in several seaweeds, comprising up to 32-35\% of dry weight [refer to Table 1 in Kadam et al. (2015)]. Chrysolaminarin is the food reserve polysaccharide in diatoms, and it is comprised only of glucose molecules (G-chains) at the reducing end (Beattie et al., 1961; Michel et al., 2010).

Glycogen is the food reserve form in cyanobacteria. Glycogen is made of glucose subunits that are linked together by $\alpha-(1 \rightarrow 4)$ and $\alpha-(1 \rightarrow 6)$ glycosidic bonds. Glycogen and amylopectin (one of starch granule constituents) are similar in structure; however, glycogen is more branched and forms smaller granules (diameter is $42 \mathrm{~nm}$ ) in comparison to starch granules (diameter 100-100,000 nm) (Ball et al., 2011).

In addition to the previously described major polysaccharide forms, other granule forms exist among algae but to a lesser degree. For instance, algae of the class Euglenophyta store their food reserves in the cytoplasm as paramylon. The granules of paramylon (or paramylum) are membrane bound and are composed of linear $\beta-(1 \rightarrow 3)$ glucan repeating units (Table 2). Its chemical structure is similar to that of laminarin but does not form $\beta-(1 \rightarrow 6)$ branches (Barsanti et al., 2011; Monfils et al., 2011).

Mannitol is a sugar alcohol of the aldohexose D-mannose. In brown algae, it serves as a storage sugar, and an antioxidant, and protects against osmotic stress. It accumulates in the cell as a monosaccharide (i.e., free mannitol sugar) and as part of the laminarin polysaccharide - forming the laminarin M-chain, where mannitol is at the reducing end (see laminarin above) (Davis et al., 2003). Mannitol is one of the major storage carbohydrates in brown algae, and some brown algae accumulate high amounts of mannitol reaching approximately $25 \%$ of Laminaria hyperborea, 30\% of Laminaria japonica, and 33\% of several Sargassum and Turbinaria dry weight (Ota et al., 2013). Mannitol is produced in brown algae from fructose-6-phosphate, which is reduced to mannitol-1-phosphate via Mannitol-1phosphate 5-dehydrogenase (EC1.1.1.17). In the second step, mannitol-1-phosphate is converted to $\mathrm{D}$-mannitol by mannitol1-phosphatase (EC3.1.3.22) [see Figure 1B (b) in Iwamoto and Shiraiwa (2005)].

\section{Structural Polysaccharides}

Structural polysaccharides are another putative source to increase bioethanol yield from algae. Their main function is to confer rigidity to the algal cell wall. In contrast to plants, which usually have a lignocellulosic cell wall, the composition of algal cell wall 
TABLE 3 | The advantages and disadvantages of employing different algal sugars for the production of third-generation biofuels.

\begin{tabular}{ll}
\hline Algal sugar & Advantages and disadvantages \\
\hline Starch & Advantages: \\
& (1) Abundant polysaccharide that is synthesized by green algae and several plants. \\
(2) There are abundant sources for amylolytic enzymes. \\
(3) The availability of genetically engineered microbes that can simultaneously hydrolyze starch and ferment it to ethanol. \\
Disadvantages: \\
(1) Starch annual production from green algae is significantly lower than floridean starch from red algae and laminarin from brown algae.
\end{tabular}

Floridean starch Advantages:

(1) The annual production levels of floridean starch from red macroalgae are hundreds of times more than starch from green micro- and macroalgae.

(2) The chemical structure is similar to starch, therefore can be degraded by the amylolytic enzymes, and fermented by microbial strains that ferment starch.

Disadvantages:

(1) There are only few scientific studies that investigated bioethanol production from floridean starch.

Glycogen Advantages:

(1) Can be easily extracted from cyanobacteria.

(2) Similar to starch, therefore can be degraded by the amylolytic enzymes, and fermented by microbial strains that ferment starch.

Disadvantages:

(1) Glycogen annual production is significantly lower than floridean starch and laminarin.

Laminarin, Advantages:

chrysolaminarin, (1) The annual production levels of laminarin-type polysaccharides are hundreds of times more than starch from green algae.

and paramylon (2) The chemical structure is similar to fungal cell wall $\beta$-glucans, and thus lytic enzymes that hydrolyze fungal cell wall can be utilized to degrade laminarin-type polysaccharides.

Disadvantages:

(1) There are only few scientific studies that investigated bioethanol production from laminarin-type polysaccharides.

Mannitol

Advantages:

(1) Soluble simple sugar that does not require hydrolysis process

(2) Accumulate in brown algae in high concentrations.

Disadvantages:

(1) Must be converted into fructose-6-phosphate before fermentation.

Cellulose Advantages

(1) Abundant polysaccharide that is synthesized by most of algae and all plants.

(2) There are abundant sources for cellulolytic enzymes.

Disadvantages:

(1) Rigid polysaccharide that requires a pretreatment step before hydrolysis.

Agarose Advantages:

(1) High annual production from red algae.

Disadvantages:

(1) Low solubility and therefore requires pretreatment before enzymatic hydrolysis.

(2) The enzymatic hydrolysis of agarose produces a non-fermentable sugar, 3,6-anhydro-L-galactose, which must be converted into fermentable sugar using agar-degrading microorganisms.

Carrageenan Advantages:

(1) High annual production from red algae.

Disadvantage:

(1) Carrageenolytic enzymes are not common among microbes.

(2) The enzymatic hydrolysis of carrageenan produces a non-fermentable sugar, 3,6-anhydro-D-galactose, which must be converted into fermentable sugar using carrageenan-degrading microorganisms.

Alginate Advantages:

(1) High annual production from brown algae.

Disadvantages:

(1) Fermentation of alginate requires genetically engineered strains.

varies among algal groups. Cellulose is the major algal cell wall polysaccharide, and it is present in most algal groups. In addition to cellulose, algae incorporate significant amounts of other polysaccharides into their cell wall, which can be converted into ethanol. Such polysaccharides can be specific to an algal group, such as the red algae, which contain agarose and carrageenan; and the brown algae, which are rich in alginate (Vreeland and Kloareg, 2000; Murphy et al., 2013). Variations in algal cell wall 
contents can also be found within families and genera of the same group. For example, the cell wall of the green seaweeds Ulva and Enteromorpha sp. contains high amounts of ulvan, while fucoidan is found in the members of family Laminariaceae of the brown algae (Jiao et al., 2011; Ale and Meyer, 2013).

Cellulose is a homopolysaccharide made of a linear chain of D-glucose units, which are connected together by $\beta$ - $(1 \rightarrow 4)$ glycosidic bonds (Table 2). Cellulose chains aggregate together by intra- and inter-molecular hydrogen bonds to form cellulose microfibrils. Microfibrils are packed together to form fibrils, which in turn aggregate to form cell wall fibers (Brown and Saxena, 2000; Pu et al., 2013). With exception to diatoms, cellulose is found in the majority of algal cell walls.

Agarose is a non-sulfated, non-water-soluble linear galactan that is composed of repeating disaccharide units of D-galactose (D-Gal) and 3,6-anhydro-L-galactose (L-AnGal). The repeating disaccharide unit is called agarobiose or neoagarobiose depending on (1) the position of each sugar in the disaccharide, (2) the bond that links the monomers within the disaccharide, and (3) the bond that links the disaccharides to form agarose. Agarobiose consists of a D-Gal residue followed by $\mathrm{L}-\mathrm{AnGal}$ that is linked by a $\beta$ - $(1 \rightarrow 4)$ glycosidic bond. In contrast, neoagarobiose consists of $\alpha$ - $(1 \rightarrow 3)$-linked $\mathrm{L}$-AnGal and $\mathrm{D}$-Gal residues. Agarobiose and neoagarobiose units are linked by $\alpha-(1 \rightarrow 3)$ and $\beta-(1 \rightarrow 4)$, respectively (Table 2) (Renn, 1997; Fu and Kim, 2010; Delattre et al., 2011).

Carrageenan is a sulfated water-soluble linear galactan of carrabiose (or neocarrabiose) subunits (Table 2). Carrabiose and neocarrabiose are similar in structure and linkage to agarobiose and neoagarobiose, respectively (De Ruiter and Rudolph, 1997; Renn, 1997; Delattre et al., 2011).

In brown algae, alginate is one of the major cell wall sugars, besides cellulose, accounting for approximately $30-60 \%$ of the total sugars. The main function of alginate is to provide the cell wall with elasticity and rigidity to survive aquatic habitats (Dornish and Rauh, 2006). Additionally, alginate is found in the matrix of some bacterial biofilms. Although its function in bacterial biofilms is not yet fully understood, alginate has been shown to play a role in bacterial pathogenesis and epiphytism (Halverson, 2009). Alginate is a linear polysaccharide composed of $\alpha$-L-guluronate $(\mathrm{G})$ and $\beta$-D-mannuronate $(\mathrm{M})$ subunits. The $G$ and $M$ subunits are linked via 1,4-glycosidic bonds and are arranged in the form of polyM, polyG, and polyMG blocks (Table 2) (Renn, 1997; Draget et al., 2005; Hashimoto et al., 2009).

Ulvan is a water-soluble cell wall polysaccharide, which is found in green seaweeds, such as Ulva and Enteromorpha sp. (Jiao et al., 2011). The dry weight percentage of Ulvan varies between 8 and 29\% (Lahaye and Robic, 2007; Robic et al., 2008). It is comprised of sulfated rhamnose, glucuronic acid, iduronic acid, xylose, and sulfated xylose. The ratio and linkage of ulvan constituent monosaccharides vary among species [refer to Lahaye and Robic (2007)]. Nevertheless, ulvan general structure is comprised of repeating disaccharide units that are linked by $\alpha-(1 \rightarrow)$ glycosidic bond. Ulvan disaccharides are formed from [glucuronic acid - sulfated rhamnose], [iduronic acid - sulfated rhamnose], [xylose - sulfated rhamnose], and [sulfated xylose - sulfated rhamnose] monomers, which are linked by either $\alpha$ - or $\beta$-( $1 \rightarrow 4)$ glycosidic bonds (Table 2 ) (Jiao et al., 2011; Yanagisawa et al., 2013; Collén et al., 2014).

Fucoidan is a cell wall polysaccharide that is found in the members of family Laminariaceae of brown algae. The dry weight percentage of fucoidan ranges normally from 5 to $20 \%$. Fucoidan structure is heterogeneous and varies among algal species. Nevertheless, it displays a general backbone consisting of predominantly $\alpha$ - $(1 \rightarrow 2)$-linked sulfated L-fucose units and, in smaller amounts, $\alpha-(1 \rightarrow 3)$ - and $\alpha-(1 \rightarrow 4)$-1inked sulfated fucose units (Percival, 1979; Davis et al., 2003; Li et al., 2008; Ale and Meyer, 2013).

\section{ENZYMATIC CONVERSION OF ALGAL SUGARS INTO BIOETHANOL}

The process of bioethanol production from algal polysaccharides consists of three major steps: biomass pretreatment, enzymatic hydrolysis of algal polysaccharides, and fermentation of sugar monomers to ethanol. The pretreatment step disrupts algal cell and releases intracellular sugars. Additionally, the pretreatment step reduces algal cell wall crystallinity making its polysaccharides accessible for enzymatic hydrolysis. Algal biomass is pretreated by physical, chemical, or biological methods. This review will not cover the pretreatment step since it has been covered in detail by other reviews [refer to Harun et al. (2014)].

Subsequently, algal biomass is degraded by lytic enzymes into simple sugars and uronic acid monomers. Hydrolysis of $\alpha$-glucans (i.e., starch and floridean starch), $\beta$-glucans (i.e., laminarin, chrysolaminarin, and cellulose), and galactans (i.e., agarose and carrageenan) releases several fermentable sugars, which enter glycolysis and are fermented into ethanol. In contrast, industrial production of ethanol from alginate requires engineering of alginate degradation, uptake, and metabolic pathways (See Fermentation of Algal Simple Sugars and Uronic Acids to Bioethanol). Simple sugars, which are released during the conversion steps, are required for the organism's growth, while ethanol is produced as a byproduct of the fermentation process.

\section{Conversion of Starch-Type Polysaccharides to Glucose Conversion of Starch to Glucose}

Starch enzymatic hydrolysis is complex and requires the activity of several enzymes, such as $\alpha$-amylase, isoamylase, pullulanase, $\beta$-amylase, and glucoamylase. Isoamylases (E.C.3.2.1.68) and pullulanases (EC 3.2.1.41) debranch amylopectin into amylose via $\alpha$ - $(1 \rightarrow 6)$ glycosidic bond cleavage. The endo-acting $\alpha$-amylases (EC 3.2.1.1) hydrolyze amylose and amylopectin $\alpha-(1 \rightarrow 4)$ glycosidic bonds randomly, producing glucose, maltose (two glucose residues), and maltodextrins of 10-20 glucose units. The exo-acting $\beta$-amylases (EC 3.2.1.2) hydrolyze amylose from the non-reducing ends to produce predominantly maltose, which is cleaved into two glucose residues by glucoamylases (EC 3.2.1.3)

(Figure 2A) [reviewed by Van Zyl et al. (2012)].

At the industrial scale, the enzymatic hydrolysis of starch is carried out at elevated temperatures, and it is divided into 


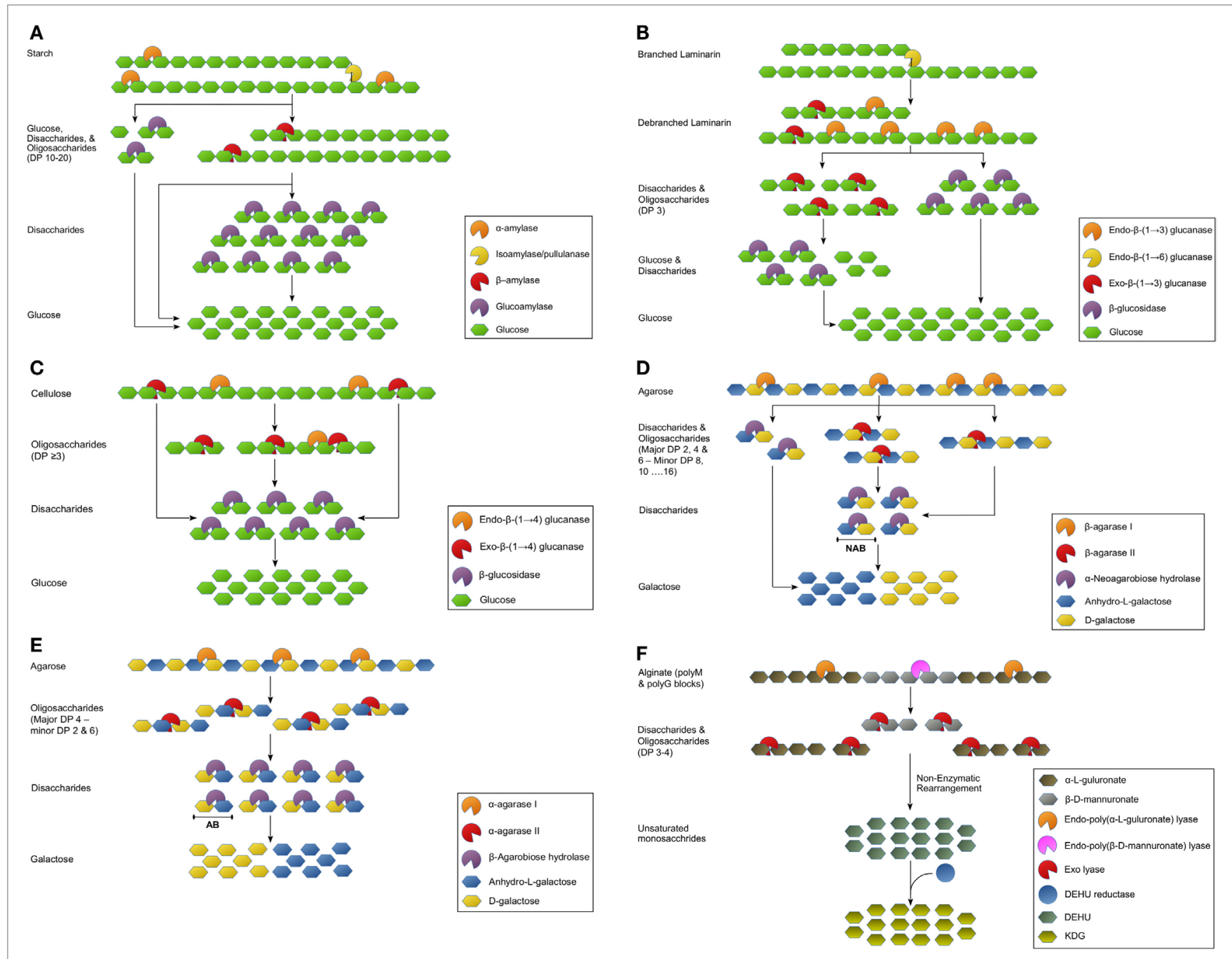

FIGURE 2 | Schematic diagrams for the enzymatic hydrolysis of algal polysaccharides. (A) Starch, floridean starch, and glycogen, (B) laminarin, chrysolaminarin, and paramylon, (C) cellulose, (D) agarose by $\beta$-agarases, (E) agarose by $\alpha$-agarases, and (F) alginate. DP, degree of polymerization; NAB, neoagarobiose; AB, agarobiose; DEHU, 4-deoxy-L-erythro-5-hexoseulose uronic acid; KDG, 2-keto-3-deoxy-gluconate; M, $\beta$-D-mannuronate; G, $\alpha$-L-guluronaten.

three steps: starch gelatinization, liquefaction, and saccharification. Starch gelatinization and liquefaction involves breaking down starch granules into a gelatinized suspension at $105^{\circ} \mathrm{C}$ followed by converting the gelatinized starch into oligosaccharides at $95^{\circ} \mathrm{C}$, respectively, using thermostable $\alpha$-amylase. Saccharification is the conversion process of oligosaccharides to primarily glucose along with other disaccharides (i.e., maltose and isomaltose) at very low concentrations. During this process, glucoamylase and isoamylase are added to hydrolyze $\alpha-(1 \rightarrow 4)$ as well as $\alpha-(1 \rightarrow 6)$ glycosidic bonds at $65^{\circ} \mathrm{C}$ (Kearsley and Dziedzic, 1995; Kulp and Ponte, 2000; Ratnayake and Jackson, 2009).

Hydrolysis of algal starch is similar to plant starch degradation steps and requires the same amylolytic enzymes [for reviews on microbial amylases, refer to Nielsen and Borchert (2000), De Souza and de Oliveira Magalhães (2010), Naidu (2013), Polizeli et al. (2013), and Saranraj and Stella (2013)].

\section{Conversion of Floridean to Glucose}

Similar to starch, gelatinized floridean starch is easier to degrade than granules and requires the same procedure of starch degradation described above (Yu et al., 2002).

\section{Conversion of Glycogen to Glucose}

Glycogen is similar in structure to amylopectin, and therefore the hydrolysis of glycogen requires the same amylolytic enzymes, which are used to breakdown starch. In fact, two reports found that only two enzymes, i.e., $\alpha$-amylase and glucoamylase, are sufficient to partially hydrolyze glycogen and allow subsequent fermentation to ethanol. However, neither the synergistic effect of these isoamylases on glycogen hydrolysis nor the final products of hydrolysis were analyzed in these studies. Therefore, the amount of glycogen degradation achieved using a combination of only $\alpha$-amylase and glucoamylase is unknown. The hydrolysis products are fermented to ethanol using budding yeast. Additionally, 
extraction of glycogen from cyanobacteria is simpler than algae as it only requires breaking down the cyanobacterial cell wall with lysozyme (Aikawa et al., 2013; Möllers et al., 2014).

\section{Conversion of Laminarin-Type Polysaccharides to Glucose}

Hydrolysis of laminarin and chrysolaminarin is catalyzed by the action of four enzymes: endo- $\beta-(1 \rightarrow 6)$ glucanases (EC 3.2.1.75), endo- $\beta-(1 \rightarrow 3)$ glucanases (EC 3.2.1.39), exo- $\beta-(1 \rightarrow 3)$ glucanases (EC 3.2.1.58), and $\beta$-glucosidases (EC 3.2.1.21). Endo- $\beta-(1 \rightarrow 6)$ glucanases debranch laminarin at the $\beta-(1 \rightarrow 6)$ linkages. Exo- $\beta-(1 \rightarrow 3)$ glucanases and endo- $\beta-(1 \rightarrow 3)$ glucanases degrade linear laminarin into laminaritriose and laminaribiose. Subsequently, laminarin oligosaccharides are lysed into glucose by $\beta$-glucosidases (Figure 2B). Degradation of the M-chain type of laminarin (i.e., with mannitol attached to the reducing end) generates small quantities of a mannitol-containing $\beta$-D-glucan (or 1-O- $\beta$-D-glucosyl-D-mannitol) (Chesters and Bull, 1963; Martin et al., 2007; Michel et al., 2010).

Paramylon is another laminarin-like starch; however, it is a linear polysaccharide and lacks $\beta$ - $(1 \rightarrow 6)$-linked branches. Therefore, degradation of paramylon to glucose is simpler than laminarin and requires the same enzymatic arsenal, with the exception of the debranching endo- $\beta-(1 \rightarrow 6)$ glucanases (Takeda et al., 2015).

\section{Conversion of Mannitol to Fructose and/or Mannose}

Mannitol is readily dissolved from algal biomass, and therefore conversion of mannitol to ethanol requires no pretreatment steps, which simplify bioethanol production process (Wang et al., 2013). In order to be fermented, mannitol must be converted to fructose-6-phosphate (fructose-6-P). Mannitol metabolic pathways vary among organisms. For example, non-lactic-acid bacteria and homofermentative lactic-acid bacteria assimilate mannitol via phosphoenolpyruvate-dependent mannitol phosphotransferase system to mannitol-1-phosphate (mannitol-1-P), which is dehydrogenated to fructose-6-P by mannitol-1-phosphate dehydrogenase (M1PDH, EC 1.1.1.17). In fungi, algae, and heterofermentative lactic-acid bacteria, mannitol is dehydrogenated by mannitol 2-dehydrogenase [M2DH, EC 1.1.1.67 (NAD), and 1.1.1.138 (NADP)] to fructose, which is phosphorylated to fructose-6-P by hexokinase (EC 2.7.1.1). In plants, mannitol is converted by mannitol 1-dehydrogenase (M1DH, EC 1.1.1.255) to mannose, which is phosphorylated to mannose-6-phosphate (mannose-6-P) by hexokinase (EC 2.7.1.1). Mannose-6-P is then converted to fructose-6-P by mannose-6-P isomerase (EC 5.3.1.8) [see Figure 1 in Iwamoto and Shiraiwa (2005)]. Finally, fructose-6-P is fermented to ethanol by ethanogenic microorganisms (See Fermentation of Algal Simple Sugars and Uronic Acids to Bioethanol).

\section{Conversion of Cellulose to Glucose}

Similar to plants, the commercial production of biofuel from algal cellulose remains a challenge since cellulose is embedded in a multilayered intricate rigid matrix of sugars and polymers, which protect cellulose from enzymatic degradation (Domozych et al.,
2012). However, the hydrolysis process of algal cell wall to ethanol remains simpler than lignocellulosic biomass because algal cell wall lacks (or contains low amounts of) lignin. Nevertheless, algal pretreatment is required to remove non-cellulosic cell wall matrix and reduce algal cellulose crystallinity making it accessible for enzymatic hydrolysis. Subsequently, cellulose is hydrolyzed by cellulolytic enzymes into glucose, which is fermented into ethanol.

Cellulose hydrolysis requires the action of several cellulolytic enzymes that cleave $\beta$-1,4-glycosidic linkages synergistically. These cellulases are endoglucanase, exoglucanase, and $\beta$-glucosidase. Endoglucanase (EC 3.2.1.4) cleaves randomly the internal $\beta$-1,4-glycosidic bonds. Exoglucanase (EC 3.2.1.91) hydrolyzes the $\beta-1,4$-glycosidic linkages of cellulose from the ends of the cellulose chain. Cellulose hydrolysis by endoglucanase and exoglucanase releases D-glucose dimer, $\beta$-cellobiose. Once $\beta$-cellobiose molecules are released, a third type of cellulases, i.e., $\beta$-glucosidase (EC 3.2.1.21) attacks $\beta$-cellobiose disaccharides and cleaves them into two glucose molecules (Figure 2C) (Pérez et al., 2002; Kuhad et al., 2011; Gupta et al., 2013).

\section{Hydrolysis of Agarose to Galactose}

The enzymatic breakdown of agarose is carried out by $\alpha$-agarases (EC 3.2.1.158) and $\beta$-agarases (EC 3.2.1.81), which hydrolyze agarose $\alpha-1,3$ and $\beta-1,4$ linkages and produce agarobiose and neoagarobiose as final hydrolysis products, respectively (Table 1). Agarobiose and neoagarobiose are further hydrolyzed by $\beta$-agarobiose hydrolase (EC is not available) and $\alpha$-neoagarobiose hydrolase (ECis not available), respectively, to produce D-galactose and anhydro-L-galactose (Figures 2D,E) (Fu and Kim, 2010; Chi et al., 2012). With exception of $\alpha$-agarases secreted by Alteromonas agaralytica and Thalassomonas sp. JAMB-A33, all characterized agarases exhibit $\beta$-agarolytic activities (Michel et al., 2006; Fu and Kim, 2010; Chi et al., 2012).

However, enzymatic hydrolysis of agarose yields low concentrations of galactose due to low solubility of agarose (Yun et al., 2015). To increase the yield, an agarose acid and heat pretreatment step (also known as chemical liquefaction) has been introduced preceding the enzymatic hydrolysis step. The chemical liquefaction process utilizes the fact that $\alpha-1,3$ linkages are hydrolyzed by acid and heat pretreatment. Such chemical liquefaction process generates slightly large (degree of polymerization >12), water soluble agarooligosaccharides, which can be quickly degraded into neoagarobiose [see Figure 1 in Kim et al. (2012)].

\section{Conversion of Carrageenan to Galactose}

The degradation of carrageenan is one of the least studied among the major cell wall carbohydrates in algae. Carrageenolytic enzymes are not common among microbes. Only few microbes have been reported to excrete carrageenases. The majority of these microbes are marine bacteria (Michel et al., 2006).

\section{Conversion of Alginate to Uronic Acid Monomers}

The degradation of alginate into unsaturated alginate oligomers (degree of polymerization 2-4) is carried out by endo-alginate 
lyases. These enzymes are classified as $\operatorname{poly}(\beta$-D-mannuronate $)$ lyase (EC 4.2.2.3) and poly( $\alpha$-L-guluronate) lyase (EC 4.2.2.11) based on their ability to hydrolyze alginate at the poly $\beta$-Dmannuronate (polyM) blocks or poly $\alpha$-L-guluronate (polyG) blocks, respectively [reviewed by Hashimoto et al. (2009) and Wong et al. (2000)]. In the next step, alginate oligomers are cleaved into unsaturated monosaccharides [4-deoxy- $\alpha$-L-erythro-hex-4enopyranuronate (DEHEP)] by exo-acting oligoalginate lyases (EC 4.2.2.26). Subsequently, DEHEP is non-enzymatically rearranged into 4-deoxy-L-erythro-5-hexoseulose uronic acid (DEHU), which is reduced to 2-keto-3-deoxy-gluconate (KDG) by DEHU reductase (EC is not available) (Figure 2F) (Wargacki et al., 2012).

\section{Degradation of Ulvans and Fucoidan}

The enzymatic hydrolysis of ulvan and fucoidan has been studied less intensively than other polysaccharides, due to several reasons. First, both sugars can be easily degraded into monomeric sugars by acid treatment (Davis et al., 2003; Feng et al., 2011). Second, ulvan and fucoidan are species-specific and familyspecific cell wall polysaccharides, respectively, and therefore only few microbes display activities against ulvan (Lahaye et al., 1997; Delattre et al., 2005; Nyvall Collén et al., 2011; Jung et al., 2013) and fucoidan [cited by Silchenko et al. (2013)].

\section{FERMENTATION OF ALGAL SIMPLE SUGARS AND URONIC ACIDS TO BIOETHANOL}

The hydrolysis of major algal polysaccharides releases several simple sugars, such as glucose, mannose, fructose, galactose, and uronic acids. These monomers are fermented to produce ethanol. Simple sugars are readily fermented to ethanol using microbial wild-type strains. In contrast, fermentation of uronic acid monomers requires genetically engineered microbes that can hydrolyze alginate to KDG and ferment it to ethanol.

\section{Microbial Fermentation of Glucose, Galactose, Fructose, and Mannose to Ethanol}

The classical budding yeast Saccharomyces cerevisiae is the most commonly used microbe for fermenting sugars to bioethanol. Additionally, the Gram-negative rod-shaped bacterium Zymomonas mobilis is used for fermentation, but to a lesser extent than the budding yeast.

Owing to their diversity, several metabolic pathways are required to convert algal sugars to ethanol. While glucose enters glycolysis directly, galactose must be converted to glucose 6-phosphate (glucose-6-P) via the Leloir pathway before entering glycolysis. Similarly, glucose isomers, such as mannose and fructose, are converted to fructose-6-phosphate (fructose-6-P), which is further metabolized through glycolysis. The conversion of fructose to fructose-6-P is simple and requires one enzyme (Hexokinase, EC 2.7.1.1). In contrast, mannose must be first phosphorylated by hexokinase (EC 2.7.1.1) to mannose6-phosphate (mannose-6-P), then isomerized to fructose-6-P by mannose-6-P isomerase (EC 5.3.1.8) [refer to Figure 2 in Van Maris et al. (2006) and Figure 1.2 in Zamora (2009)].

Once phosphorylated sugars enter glycolysis, they are metabolized to pyruvate. The major microbial glycolysis pathways are the Embden-Meyerhof-Parnas (EMP) and the Entner-Doudoroff (ED) pathway, depending on the microorganism [reviewed by Wolfe (2015)]. While S. cerevisiae utilizes the EMP pathway for metabolizing glucose, ED pathway is the common pathway for glucose metabolism in Z. mobilis. The EMP and ED pathways are divided into two multistep stages. In the first stage, glucose is converted to glyceraldehyde-3-phosphate (glyceraldehyde-3-P), which is further metabolized to pyruvate in the second stage (Figures 3A,B).

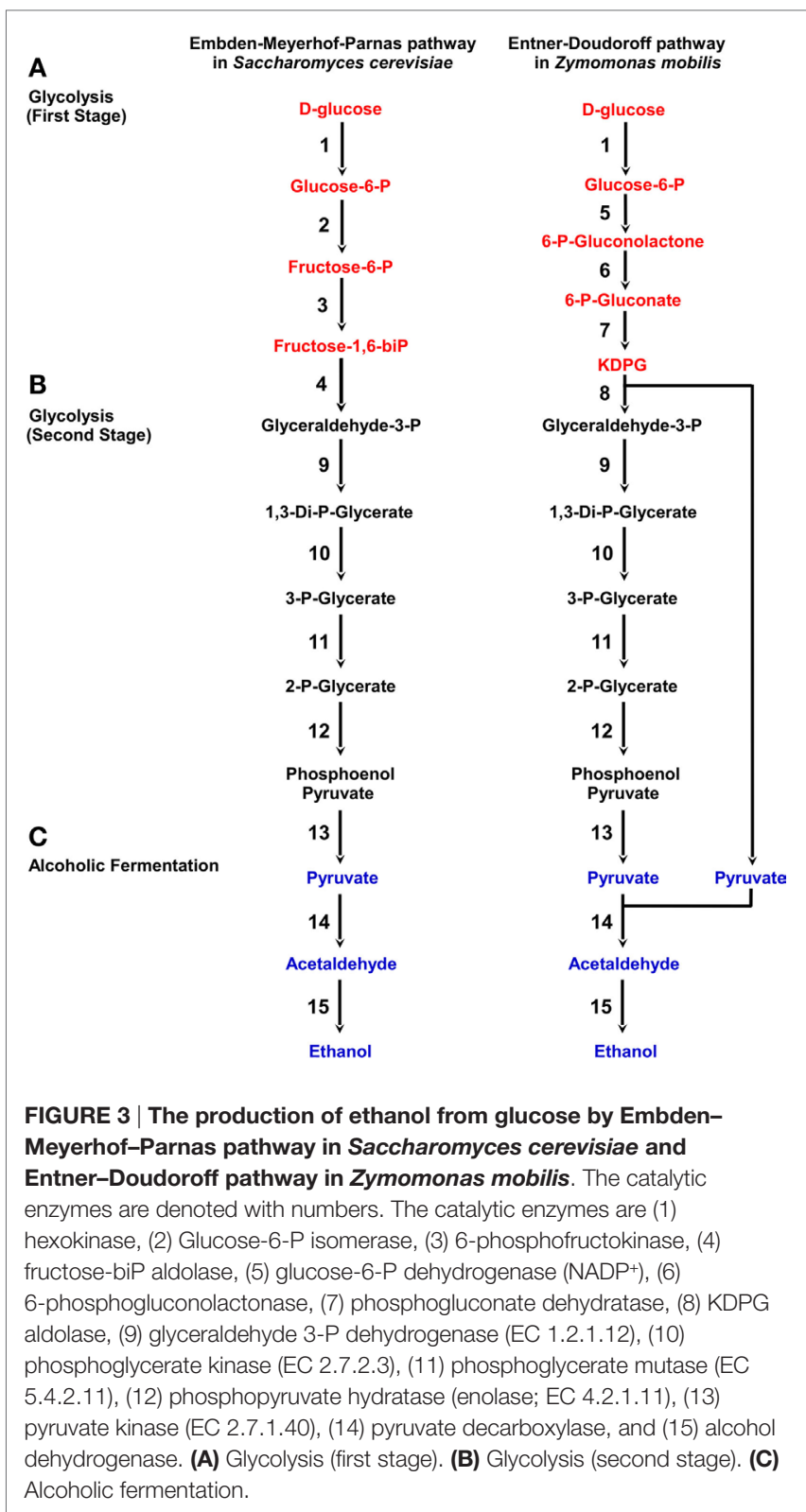


In the first stage of the EMP pathway, glucose is phosphorylated by hexokinase (EC 2.7.1.1) to glucose-6-P, which is transformed into its keto isomer fructose-6-P by glucose-6-P isomerase (EC 5.3.1.9). In the next step, the enzyme 6-phosphofructokinase (EC 2.7.1.11) phosphorylates fructose-6-P to fructose-1,6-biphosphate, which is converted to glyceraldehyde3-P by fructose-bisphosphate aldolase (EC 4.1.2.13) (Figure 3) (Flamholz et al., 2013). The first stage of the ED pathway begins with phosphorylation of glucose by hexokinase (EC 2.7.1.1) to glucose-6-P, which is oxidized to 6-phosphogluconolactone by glucose-6-P dehydrogenase $\left(\mathrm{NADP}^{+}\right)$(EC 1.1.1.49). Once oxidized, 6-phosphogluconolactone is hydrolyzed by the enzyme 6-phosphogluconolactonase (EC 3.1.1.31) to 6-phosphogluconate, which is dehydrated to 2-keto-3-deoxy-6-phosphogluconate (KDPG) by a phosphogluconate dehydratase (EC 4.2.1.12). Finally, KDPG is converted to pyruvate and glyceraldehyde-3-P by KDPG aldolase (EC 4.1.2.14) (Figure 3A) (Flamholz et al., 2013; Spaans et al., 2015).

In contrast to the first stage of EMP and ED pathways, the second stage of these two pathways is identical. During the second stage, glyceraldehyde-3-P is converted to pyruvate (summarized in Figure 3B). Following glycolysis, pyruvate is converted to ethanol primarily by a two-step alcoholic fermentation (Figure 3C). In the first step, pyruvate is converted by pyruvate decarboxylase (EC 4.1.1.1) to acetaldehyde, which is reduced to ethanol by alcohol dehydrogenase (EC 1.1.1.1).

\section{Microbial Fermentation of 3,6-Anhydro-Galactoses to Ethanol}

In addition to galactose, the enzymatic hydrolysis of agarose and carrageenan produces the non-fermentable sugars, 3,6-anhydroL-galactose (L-AnG) and 3,6-anhydro-D-galactose (D-AnG), respectively. To increase bioethanol yield from algal biomass, L-AnG and D-AnG must be converted into fermentable sugar. Metabolic pathways for L-AnG and D-AnG are only common in agar- and carrageenan-degrading microorganisms. In these organisms, L-AnG and D-AnG are converted to 2-keto-3-deoxy6-phospho-D-galactonate (D-KDPGal) through six and four enzyme-catalyzed reactions, respectively [see Figure 5 in Lee et al. (2014, 2016)]. D-KDPGal enters the DeLey-Doudoroff pathway, where it is converted to the fermentable sugars glyceraldehyde-3-phosphate and pyruvate (Lee et al., 2014, 2016). Glyceraldehyde-3-phosphate is then converted by glycolysis to pyruvate, which is metabolized to ethanol by alcoholic fermentation (Figures 3B,C).

\section{Engineered Microbes to Metabolize Uronic Acid Monomers to Ethanol}

Several microorganisms, which can metabolize alginate, have been identified [reviewed by Wong et al. (2000)]. In these microbes, the hydrolysis of alginate results in DEHU. To ferment it to ethanol, DEHU must be first reduced to KDG by DEHU reductase (EC is not available) (Wargacki et al., 2012). Then, KDG is phosphorylated to KDPG, i.e., KDPG by KDG kinase (EC 2.7.1.45). Finally, KDPG enters the ED pathway, where it is cleaved by KDPG aldolase (EC 4.1.2.14) to pyruvate and glyceraldehyde-3-phosphate and fermented to ethanol [refer to Supplementary Figure 1 in Enquist-Newman et al. (2014)].

However, the commercial production of ethanol from alginate is challenged by the lack of robust microorganisms that can simultaneously digest, metabolize, and ferment alginate to ethanol at the industrial level. While alginolytic microbes lack the robustness for the production of ethanol at large scale, major ethanologenic microbes, such as S. cerevisiae, Z. mobilis, and E. coli, cannot degrade and metabolize alginate. To overcome this challenge, strains that can simultaneously degrade, metabolize, and ferment alginate to ethanol were engineered. The molecular engineering of alginate and mannitol metabolic pathways in $S$. cerevisiae results in a strain that can simultaneously ferment up to $83 \%$ of brown algae theoretical total sugars (i.e., alginate, mannitol, and glucose) to ethanol. The strain, which expresses the DEHU transporter gene from the marine fungus Asteromyces cruciatus and alginate metabolism genes from bacterial origin, is capable of degrading alginate to uronic acid monomers. These monomers are then converted to ethanol (Enquist-Newman et al., 2014).

Similarly, a plasmid-based E. coli strain, which is capable of simultaneous degradation and fermentation of alginate to ethanol, was engineered using alginate metabolic pathway genes from Vibrio splendidus. This strain, which can metabolize alginate, mannitol, and laminarin, fermented $80 \%$ of the maximum theoretical yield and produces 0.281 weight ethanol/weight dry macroalgae (Wargacki et al., 2012). Ethanol productivity of this strain was further enhanced using recombinase-assisted genome engineering (RAGE). The resulting engineered strain, which integrates alginate metabolism genes into its genome, produced a $330 \%$ higher titer than the canonical plasmid-based E. coli counterpart after culturing both strains on synthetic seaweed medium for 50 generations (Santos et al., 2013).

\section{CONCLUSION AND FUTURE DIRECTIONS}

Algae accumulate high amount of carbohydrates, which can be used to produce bioethanol. However the hydrolysis process of algal polysaccharides requires more enzymatic mixtures than plants. Significant amount of research has been done to decipher the hydrolysis processes of different algal sugars and identify their corresponding hydrolytic enzymes. However, one of the major challenges - within the context of the enzymatic hydrolysis of algal polysaccharides - is to identify hydrolytic enzymes that can breakdown algal-specific sugars, such as agarose, carrageenan, ulvans, and fucoidan. This requires the identification of new marine microorganisms, which thrive growing on algae. Additionally, identification of their enzymatic systems via a combination of genomics, transcriptomics, and proteomics approaches will enable high-throughput protein analysis in these microbes. Furthermore, traditional breeding and genetic engineering can be implemented to generate microbial strains that can hydrolyze algal carbohydrates. Protein engineering is another powerful tool to generate enzymes with novel properties. A wider range of $\mathrm{pH}$-, temperature-, and 
salinity-tolerance levels, as well as broader substrate activities and higher conversion rates are desirable properties for bioethanol production from algae. Owing to their diversity, the fermentation of algal monosaccharides requires several metabolic pathways. Therefore, engineered strains, which can ferment several monosaccharides to ethanol, will simplify the conversion processes. Indeed, the best situation is to generate microbial strains, which can simultaneously hydrolyze and ferment total algal sugars to ethanol.

\section{REFERENCES}

Aikawa, S., Joseph, A., Yamada, R., Izumi, Y., Yamagishi, T., Matsuda, F., et al. (2013). Direct conversion of Spirulina to ethanol without pretreatment or enzymatic hydrolysis processes. Energy Environ. Sci. 6, 1844-1849. doi:10.1039/ C3EE40305J

Ale, M. T., and Meyer, A. S. (2013). Fucoidans from brown seaweeds: an update on structures, extraction techniques and use of enzymes as tools for structural elucidation. RSC Adv. 3, 8131-8141. doi:10.1039/C3RA23373A

Avigad, G., and Dey, P. M. (1997). “4 - carbohydrate metabolism: storage carbohydrates," in Plant Biochemistry, eds P. M. Dey and J. B. Harborne (London: Academic Press), 143-204.

Badger, P. C. (2002). "Ethanol from cellulose: a general review," in Trends in New Crops and New Uses. Proceedings of the Fifth National Symposium, eds J. Janick and A. Whipkey (Alexandria, VA: ASHS Press), 17-21.

Ball, S., Colleoni, C., Cenci, U., Raj, J. N., and Tirtiaux, C. (2011). The evolution of glycogen and starch metabolism in eukaryotes gives molecular clues to understand the establishment of plastid endosymbiosis. J. Exp. Bot. 62, 1775-1801. doi:10.1093/jxb/erq411

Barsanti, L., Passarelli, V., Evangelista, V., Frassanito, A. M., and Gualtieri, P. (2011). Chemistry, physico-chemistry and applications linked to biological activities of $\beta$-glucans. Nat. Prod. Rep. 28, 457-466. doi:10.1039/C0NP00018C

Beattie, A., Hirst, E. L., and Percival, E. (1961). Studies on the metabolism of the Chrysophyceae. Comparative structural investigations on leucosin (chrysolaminarin) separated from diatoms and laminarin from the brown algae. Biochem. J. 79, 531-537. doi:10.1042/bj0790531

Behera, S., Singh, R., Arora, R., Sharma, N. K., Shukla, M., and Kumar, S. (2015). Scope of algae as third generation biofuels. Front. Bioeng. Biotechnol. 2:90. doi:10.3389/fbioe.2014.00090

Benemann, J. (2013). Microalgae for biofuels and animal feeds. Energies 6, 5869-5886. doi:10.3390/en6115869

Borowitzka, M. A. (2013). "Energy from microalgae: a short history," in Algae for Biofuels and Energy Developments in Applied Phycology, eds M. A. Borowitzka and N. R. Moheimani (Netherlands: Springer), 1-15.

Brennan, L., and Owende, P. (2010). Biofuels from microalgae - a review of technologies for production, processing, and extractions of biofuels and co-products. Renew. Sustain. Energy Rev. 14, 557-577. doi:10.1016/j.rser.2009.10.009

Brodie, J., and Lewis, J. (2007). Unravelling the Algae: The Past, Present, and Future of Algal Systematics. Boca Raton, FL: CRC Press.

Brown, R. M., and Saxena, I. M. (2000). Cellulose biosynthesis: a model for understanding the assembly of biopolymers. Plant Physiol. Biochem. 38, 57-67. doi:10.1016/S0981-9428(00)00168-6

Bruton, T., Lyons, H., Lerat, Y., Stanley, M., and Rasmussen, M. B. (2009). A Review of the Potential of Marine Algae as a Source of Biofuel in Ireland. Dublin, Ireland: Sustainable Energy Ireland.

Busi, M. V., Barchiesi, J., Martín, M., and Gomez-Casati, D. F. (2014). Starch metabolism in green algae. Starch - Stärke 66, 28-40. doi:10.1002/star.201200211

Carlsson, A. S., van Beilen, J. B., Möller, R., and Clayton, D. (2007). Micro- and Macro-Algae: Utility for Industrial Applications: Outputs from the EPOBIO Project. Chippenham, England: CPL Press.

Chen, C.-Y., Zhao, X.-Q., Yen, H.-W., Ho, S.-H., Cheng, C.-L., Lee, D.-J., et al. (2013). Microalgae-based carbohydrates for biofuel production. Biochem. Eng. J. 78, 1-10. doi:10.1016/j.bej.2013.03.006

Chen, P., Min, M., Chen, Y., Wang, L., Li, Y., Chen, Q., et al. (2010). Review of biological and engineering aspects of algae to fuels approach. Int. J. Agric. Biol. Eng. 2, 1-30. doi:10.3965/ijabe.v2i4.200

\section{AUTHOR CONTRIBUTIONS}

QA is the main author. JF and BN contributed substantially to the work reported.

\section{FUNDING}

The study was funded by U.S. Department of Energy; prime DOE award: DE-SC0006838.

Chesters, C. G. C., and Bull, A. T. (1963). The enzymic degradation of laminarin. 1. The distribution of laminarinase among micro-organisms. Biochem. J. 86, 28-31. doi:10.1042/bj0860028

Chi, W.-J., Chang, Y.-K., and Hong, S.-K. (2012). Agar degradation by microorganisms and agar-degrading enzymes. Appl. Microbiol. Biotechnol. 94, 917-930. doi:10.1007/s00253-012-4023-2

Chisti, Y. (2016). "Large-scale production of algal biomass: raceway ponds," in Algae Biotechnology: Products and Processes, eds F. Bux and Y. Chisti (Cham: Springer International Publishing), 21-40. doi:10.1007/978-3-319-12334-9_2

Ciferri, O. (1983). Spirulina, the edible microorganism. Microbiol. Rev. 47, 551-578.

Collén, P. N., Jeudy, A., Sassi, J.-F., Groisillier, A., Czjzek, M., Coutinho, P. M., et al. (2014). A novel unsaturated $\beta$-glucuronyl hydrolase involved in ulvan degradation unveils the versatility of stereochemistry requirements in family GH105. J. Biol. Chem. 289, 6199-6211. doi:10.1074/jbc.M113. 537480

Dahiya, A. (2015). Bioenergy: Biomass to Biofuels, 1st Edn. Boston: Academic Press.

Davis, T. A., Volesky, B., and Mucci, A. (2003). A review of the biochemistry of heavy metal biosorption by brown algae. Water Res. 37, 4311-4330. doi:10.1016/ S0043-1354(03)00293-8

De Ruiter, G. A., and Rudolph, B. (1997). Carrageenan biotechnology. Trends Food Sci. Technol. 8, 389-395. doi:10.1016/S0924-2244(97)01091-1

De Souza, P. M., and de Oliveira Magalhães, P. (2010). Application of microbial $\alpha$-amylase in industry - a review. Braz. J. Microbiol. 41, 850-861. doi:10.1590/ S1517-83822010000400004

Delattre, C., Fenoradosoa, T. A., and Michaud, P. (2011). Galactans: an overview of their most important sourcing and applications as natural polysaccharides. Braz. Arch. Biol. Technol. 54, 1075-1092. doi:10.1590/S1516-89132011000600002

Delattre, C., Michaud, P., Keller, C., Elboutachfaiti, R., Beven, L., Courtois, B., et al. (2005). Purification and characterization of a novel glucuronan lyase from Trichoderma sp. GL2. Appl. Microbiol. Biotechnol. 70, 437-443. doi:10.1007/ s00253-005-0077-8

Deschamps, P., Haferkamp, I., d'Hulst, C., Neuhaus, H. E., and Ball, S. G. (2008). The relocation of starch metabolism to chloroplasts: when, why and how. Trends Plant Sci. 13, 574-582. doi:10.1016/j.tplants.2008.08.009

Dexter, J., Armshaw, P., Sheahan, C., and Pembroke, J. T. (2015). The state of autotrophic ethanol production in Cyanobacteria. J. Appl. Microbiol. 119, 11-24. doi:10.1111/jam.12821

Domozych, D. S., Ciancia, M., Fangel, J. U., Mikkelsen, M. D., Ulvskov, P., and Willats, W. G. T. (2012). The cell walls of green algae: a journey through evolution and diversity. Front. Plant Sci. 3:82. doi:10.3389/fpls.2012.00082

Dornish, M., and Rauh, F. (2006). "Alginate," in An Introduction to Biomaterials, eds S. A. Guelcher and J. O. Hollinger (Boca Raton, FL: CRC Press), 261-272.

Draget, K. I., Smidsrød, O., and Skjåk-Braek, G. (2005). Alginates from algae. Biopolymers 6. doi:10.1002/3527600035.bpol6008

Enquist-Newman, M., Faust, A. M. E., Bravo, D. D., Santos, C. N. S., Raisner, R. M., Hanel, A., et al. (2014). Efficient ethanol production from brown macroalgae sugars by a synthetic yeast platform. Nature 505, 239-243. doi:10.1038/ nature 12771

Feng, D., Liu, H., Li, F., Jiang, P., and Qin, S. (2011). Optimization of dilute acid hydrolysis of Enteromorpha. Chin. J. Oceanol. Limnol. 29, 1243-1248. doi:10.1007/s00343-011-0298-x

Fengel, D., and Gert, W. (1989). Wood: Chemistry, Ultrastructure, Reactions. Berlin, Germany: Walter de Gruyter \& Co.

Flamholz, A., Noor, E., Bar-Even, A., Liebermeister, W., and Milo, R. (2013). Glycolytic strategy as a tradeoff between energy yield and protein cost. Proc. Natl. Acad. Sci. U.S.A. 110, 10039-10044. doi:10.1073/pnas.1215283110 
Fu, X. T., and Kim, S. M. (2010). Agarase: review of major sources, categories, purification method, enzyme characteristics and applications. Mar. Drugs 8, 200-218. doi:10.3390/md8010200

Grant Reid, J. S. (1997). “5 - carbohydrate metabolism: structural carbohydrates," in Plant Biochemistry, eds P. M. Dey and J. B. Harborne (London: Academic Press), 205-236.

Groom, M. J., Gray, E. M., and Townsend, P. A. (2008). Biofuels and biodiversity: principles for creating better policies for biofuel production. Conserv. Biol. 22, 602-609. doi:10.1111/j.1523-1739.2007.00879.x

Gupta, R., Mehta, G., Deswal, D., Sharma, S., Jain, K. K., Kuhad, R. C., et al. (2013). "Cellulases and their biotechnological applications," in Biotechnology for Environmental Management and Resource Recovery, eds R. C. Kuhad and A. Singh (India: Springer), 89-106.

Habib, M. A. B., Parvin, M., Huntington, T. C., and Hasan, M. R. (2008). A Review on Culture, Production and Use of Spirulina as Food for Humans and Feeds for Domestic Animals and Fish. Rome: FAO.

Halverson, L. J. (2009). "Role of alginate in bacterial biofilms," in Alginates: Biology and Applications, ed. B. H. A. Rehm (Berlin, Heidelberg: Springer), 135-151.

Hannon, M., Gimpel, J., Tran, M., Rasala, B., and Mayfield, S. (2010). Biofuels from algae: challenges and potential. Biofuels 1, 763-784. doi:10.4155/bfs.10.44

Harun, R., Yip, J. W. S., Thiruvenkadam, S., Ghani, W. A. W. A. K., Cherrington, T., and Danquah, M. K. (2014). Algal biomass conversion to bioethanol - a step-by-step assessment. Biotechnol. J. 9, 73-86. doi:10.1002/biot.201200353

Hashimoto, W., Maruyama, Y., Itoh, T., Mikami, B., and Murata, K. (2009). "Bacterial system for alginate uptake and degradation," in Alginates: Biology and Applications, ed. B. H. A. Rehm (Berlin, Heidelberg: Springer), 73-94.

Hughes, A. D., Kelly, M. S., Black, K. D., and Stanley, M. S. (2012). Biogas from macroalgae: is it time to revisit the idea? Biotechnol. Biofuels 5, 86. doi:10.1186/1754-6834-5-86

Iwamoto, K., and Shiraiwa, Y. (2005). Salt-regulated mannitol metabolism in algae. Mar. Biotechnol. 7, 407-415. doi:10.1007/s10126-005-0029-4

Jiao, G., Yu, G., Zhang, J., and Ewart, H. S. (2011). Chemical structures and bioactivities of sulfated polysaccharides from marine algae. Mar. Drugs 9, 196-223. doi:10.3390/md9020196

John, R. P., and Anisha, G. S. (2012). "Macroalgae and their potential for biofuel," in Plant Sciences Reviews 2011, ed. D. Hemming (Wallingford, UK: CABI), 151-162.

John, R. P., Anisha, G. S., Nampoothiri, K. M., and Pandey, A. (2011). Micro and macroalgal biomass: a renewable source for bioethanol. Bioresour. Technol. 102, 186-193. doi:10.1016/j.biortech.2010.06.139

Jung, K. A., Lim, S.-R., Kim, Y., and Park, J. M. (2013). Potentials of macroalgae as feedstocks for biorefinery. Bioresour. Technol. 135, 182-190. doi:10.1016/j. biortech.2012.10.025

Kadam, S. U., Tiwari, B. K., and O’Donnell, C. P. (2015). Extraction, structure and biofunctional activities of laminarin from brown algae. Int. J. Food Sci. Technol. 50, 24-31. doi:10.1111/ijfs.12692

Kearsley, M. W., and Dziedzic, S. Z. (1995). Handbook of Starch Hydrolysis Products and Their Derivatives. New York: Springer.

Kim, H. T., Lee, S., Kim, K. H., and Choi, I.-G. (2012). The complete enzymatic saccharification of agarose and its application to simultaneous saccharification and fermentation of agarose for ethanol production. Bioresour. Technol. 107, 301-306. doi:10.1016/j.biortech.2011.11.120

Kim, S.-K. (2015). Handbook of Marine Microalgae: Biotechnology Advances. Boston: Academic Press.

Kuhad, R. C., Gupta, R., and Singh, A. (2011). Microbial cellulases and their industrial applications. Enzyme Res. 2011, 280696. doi:10.4061/2011/280696

Kulp, K., and Ponte, J. G. (2000). Handbook of Cereal Science and Technology. New York, NY: Marcel Dekker Inc.

Lahaye, M., Brunel, M., and Bonnin, E. (1997). Fine chemical structure analysis of oligosaccharides produced by an ulvan-lyase degradation of the water-soluble cell-wall polysaccharides from Ulva sp, (Ulvales, Chlorophyta). Carbohydr. Res. 304, 325-333. doi:10.1016/S0008-6215(97)00270-X

Lahaye, M., and Robic, A. (2007). Structure and functional properties of ulvan, a polysaccharide from green seaweeds. Biomacromolecules 8, 1765-1774. doi:10.1021/bm061185q

Lee, S. B., Cho, S. J., Kim, J. A., Lee, S. Y., Kim, S. M., and Lim, H. S. (2014). Metabolic pathway of 3,6-anhydro-L-galactose in agar-degrading microorganisms. Biotechnol. Bioprocess Eng. 19, 866-878. doi:10.1007/ s12257-014-0622-3
Lee, S. B., Kim, J. A., and Lim, H. S. (2016). Metabolic pathway of 3,6-anhydro-D-galactose in carrageenan-degrading microorganisms. Appl. Microbiol. Biotechnol. 100, 4109-4121. doi:10.1007/s00253-016-7346-6

Lee, Y.-K. (1997). Commercial production of microalgae in the Asia-Pacific rim. J. Appl. Phycol. 9, 403-411. doi:10.1023/A:1007900423275

Li, B., Lu, F., Wei, X., and Zhao, R. (2008). Fucoidan: structure and bioactivity. Molecules 13, 1671-1695. doi:10.3390/molecules13081671

Lüning, K., and Pang, S. (2003). Mass cultivation of seaweeds: current aspects and approaches. J. Appl. Phycol. 15, 115-119. doi:10.1023/A:1023807503255

Martin, K., McDougall, B. M., McIlroy, S., Chen, J., and Seviour, R. J. (2007). Biochemistry and molecular biology of exocellular fungal $\beta-(1,3)-$ and $\beta$-(1,6)-glucanases. FEMS Microbiol. Rev. 31, 168-192. doi:10.1111/ j.1574-6976.2006.00055.x

Mata, T. M., Martins, A. A., and Caetano, N. S. (2010). Microalgae for biodiesel production and other applications: a review. Renew. Sustain. Energy Rev. 14, 217-232. doi:10.1016/j.rser.2009.07.020

Metting, F. B. (1996). Biodiversity and application of microalgae. J. Ind. Microbiol. 17, 477-489. doi:10.1007/BF01574779

Michel, G., Nyval-Collen, P., Barbeyron, T., Czjzek, M., and Helbert, W. (2006). Bioconversion of red seaweed galactans: a focus on bacterial agarases and carrageenases. Appl. Microbiol. Biotechnol. 71, 23-33. doi:10.1007/s00253-0060377-7

Michel, G., Tonon, T., Scornet, D., Cock, J. M., and Kloareg, B. (2010). Central and storage carbon metabolism of the brown alga Ectocarpus siliculosus: insights into the origin and evolution of storage carbohydrates in Eukaryotes. New Phytol. 188, 67-81. doi:10.1111/j.1469-8137.2010.03345.x

Möllers, K. B., Cannella, D., Jørgensen,H., and Frigaard,N.-U.(2014).Cyanobacterial biomass as carbohydrate and nutrient feedstock for bioethanol production by yeast fermentation. Biotechnol. Biofuels 7, 64. doi:10.1186/1754-6834-7-64

Monfils, A. K., Triemer, R. E., and Bellairs, E. F. (2011). Characterization of paramylon morphological diversity in photosynthetic euglenoids (Euglenales, Euglenophyta). Phycologia 50, 156-169. doi:10.2216/09-112.1

Moroney, J. V., and Ynalvez, R. A. (2001). Algal photosynthesis. eLS. doi:10.1002/ 9780470015902.a0000322.pub2

Motone, K., Takagi, T., Sasaki, Y., Kuroda, K., and Ueda, M. (2016). Direct ethanol fermentation of the algal storage polysaccharide laminarin with an optimized combination of engineered yeasts. J. Biotechnol. 231, 129-135. doi:10.1016/j. jbiotec.2016.06.002

Murphy, F., Devlin, G., Deverell, R., and McDonnell, K. (2013). Biofuel production in Ireland - an APPROACH to 2020 targets with a focus on algal biomass. Energies 6, 6391-6412. doi:10.3390/en6126391

Naidu, M. A. (2013). Bacterial amylase a review. Int. J. Pharm. Biol. Arch. 4, 274-287.

Naik, S. N., Goud, V. V., Rout, P. K., and Dalai, A. K. (2010). Production of first and second generation biofuels: a comprehensive review. Renew. Sustain. Energy Rev. 14, 578-597. doi:10.1016/j.rser.2009.10.003

Nielsen, J. E., and Borchert, T. V. (2000). Protein engineering of bacterial $\alpha$-amylases Biochim. Biophys. Acta 1543, 253-274. doi:10.1016/S0167-4838(00)00240-5

Nozzi, N. E., Oliver, J. W. K., and Atsumi, S. (2013). Cyanobacteria as a platform for biofuel production. Front. Bioeng. Biotechnol. 1:7. doi:10.3389/fbioe.2013. 00007

Nyvall Collén, P., Sassi, J.-F., Rogniaux, H., Marfaing, H., and Helbert, W. (2011). Ulvan lyases isolated from the flavobacteria Persicivirga ulvanivorans are the first members of a new polysaccharide lyase family. J. Biol. Chem. 286, 42063-42071. doi:10.1074/jbc.M111.271825

Ota, A., Kawai, S., Oda, H., Iohara, K., and Murata, K. (2013). Production of ethanol from mannitol by the yeast strain Saccharomyces paradoxus NBRC 0259. J. Biosci. Bioeng. 116, 327-332. doi:10.1016/j.jbiosc.2013.03.018

Packer, M. (2009). Algal capture of carbon dioxide; biomass generation as a tool for greenhouse gas mitigation with reference to New Zealand energy strategy and policy. Energy Policy 37, 3428-3437. doi:10.1016/j.enpol.2008. 12.025

Peat, S., and Turvey, J. R. (1965). "Polysaccharides of marine algae," in Fortschritte der Chemie Organischer Naturstoffe/Progress in the Chemistry of Organic Natural Products/Progrès dans la Chimie des Substances Organiques Naturelles, ed. L. Zechmeister (Vienna: Springer), 1-45.

Percival, E. (1970). "Algal polysaccharides," in Algal Polysaccharides The Carbohydrates: Chemistry and Biochemistry, eds W. Pigman and D. Horton (New York, NY: Academic Press, Inc), 537-568. 
Percival, E. (1979). The polysaccharides of green, red and brown seaweeds: their basic structure, biosynthesis and function. Br. Phycol. J. 14, 103-117. doi:10.1080/00071617900650121

Pérez, J., Muñoz-Dorado, J., de la Rubia, T., and Martínez, J. (2002). Biodegradation and biological treatments of cellulose, hemicellulose and lignin: an overview. Int. Microbiol. 5, 53-63. doi:10.1007/s10123-002-0062-3

Polizeli, M., de, L. T. M., and Rai, M. (2013). Fungal Enzymes. New York, NY: CRC Press.

Pruvost, J., Cornet, J.-F., and Pilon, L. (2016). "Large-scale production of algal biomass: photobioreactors," in Algae Biotechnology: Products and Processes, eds F. Bux and Y. Chisti (Cham: Springer International Publishing), 41-66. doi:10.1007/978-3-319-12334-9_3

$\mathrm{Pu}, \mathrm{Y}$., Hu, F., Huang, F., Davison, B. H., and Ragauskas, A. J. (2013). Assessing the molecular structure basis for biomass recalcitrance during dilute acid and hydrothermal pretreatments. Biotechnol. Biofuels 6, 15. doi:10.1186/17546834-6-15

Quintana, N., Van der Kooy, F., Van de Rhee, M. D., Voshol, G. P., and Verpoorte, R. (2011). Renewable energy from Cyanobacteria: energy production optimization by metabolic pathway engineering. Appl. Microbiol. Biotechnol. 91, 471-490. doi:10.1007/s00253-011-3394-0

Radakovits, R., Jinkerson, R. E., Darzins, A., and Posewitz, M. C. (2010). Genetic engineering of algae for enhanced biofuel production. Eukaryot. Cell 9, 486-501. doi:10.1128/EC.00364-09

Rajkumar, R., Yaakob, Z., and Takriff, M. S. (2014). Potential of micro and macro algae for biofuel production: a brief review. BioResources 9, 1606-1633. doi:10.15376/biores.9.1.1606-1633

Ramaiah, N. (2006). A review on fungal diseases of algae, marine fishes, shrimps and corals. Indian J. Mar. Sci. 35, 380-387.

Ratnayake, W. S., and Jackson, D. S. (2009). Starch gelatinization. Adv. Food Nutr. Res. 55, 221-268. doi:10.1016/S1043-4526(08)00405-1

Renn, D. (1997). Biotechnology and the red seaweed polysaccharide industry: status, needs and prospects. Trends Biotechnol. 15, 9-14. doi:10.1016/ S0167-7799(96)10069-X

Robic, A., Bertrand, D., Sassi, J.-F., Lerat, Y., and Lahaye, M. (2008). Determination of the chemical composition of ulvan, a cell wall polysaccharide from Ulva spp. (Ulvales, Chlorophyta) by FT-IR and chemometrics. J. Appl. Phycol. 21, 451-456. doi:10.1007/s10811-008-9390-9

Santos, C. N. S., Regitsky, D. D., and Yoshikuni, Y. (2013). Implementation of stable and complex biological systems through recombinase-assisted genome engineering. Nat. Commun. 4, 2503. doi:10.1038/ncomms3503

Saranraj, P., and Stella, D. (2013). Fungal amylase - a review. Int. J. Microbiol. Res. 4, 203-211. doi:10.5829/idosi.ijmr.2013.4.2.75170

Sarsekeyeva, F., Zayadan, B. K., Usserbaeva, A., Bedbenov, V. S., Sinetova, M. A., and Los, D. A. (2015). Cyanofuels: biofuels from cyanobacteria. Reality and perspectives. Photosynth. Res. 125, 329-340. doi:10.1007/s11120-0150103-3

Satyanarayana, K. G., Mariano, A. B., and Vargas, J. V. C. (2011). A review on microalgae, a versatile source for sustainable energy and materials. Int. J. Energy Res 35, 291-311. doi:10.1002/er.1695

Scaife, M. A., Merkx-Jacques, A., Woodhall, D. L., and Armenta, R. E. (2015). Algal biofuels in Canada: status and potential. Renew. Sustain. Energy Rev. 44, 620-642. doi:10.1016/j.rser.2014.12.024

Searchinger, T., Heimlich, R., Houghton, R. A., Dong, F., Elobeid, A., Fabiosa, J., et al. (2008). Use of U.S. Croplands for biofuels increases greenhouse gases through emissions from land-use change. Science 319, 1238-1240. doi:10.1126/ science. 1151861

Sheath, R. G., Hellebust, J. A., and Sawa, T. (1981). Ultrastructure of the floridean starch granule. Phycologia 20, 292-297. doi:10.2216/i0031-8884-20-3-292.1

Silchenko, A. S., Kusaykin, M. I., Kurilenko, V. V., Zakharenko, A. M., Isakov, V. V., Zaporozhets, T. S., et al. (2013). Hydrolysis of fucoidan by fucoidanase isolated from the marine bacterium, Formosa algae. Mar. Drugs 11, 2413-2430. doi: $10.3390 / \mathrm{md} 11072413$

Singh, A., Nigam, P. S., and Murphy, J. D. (2011). Mechanism and challenges in commercialisation of algal biofuels. Bioresour. Technol. 102, 26-34. doi:10.1016/j.biortech.2010.06.057

Spaans, S. K., Weusthuis, R. A., van der Oost, J., and Kengen, S. W. M. (2015). NADPH-generating systems in bacteria and archaea. Front. Microbiol. 6:742. doi:10.3389/fmicb.2015.00742
Suutari, M., Leskinen, E., Fagerstedt, K., Kuparinen, J., Kuuppo, P., and Blomster, J. (2015). Macroalgae in biofuel production. Phycol. Res. 63, 1-18. doi:10.1111/ pre. 12078

Synytsya, A., Čopíková, J., Kim, W. J., and Park, Y. I. (2015). "Cell wall polysaccharides of marine algae," in Springer Handbook of Marine Biotechnology, ed. S.-K. Kim (Berlin, Heidelberg: Springer), 543-590.

Takeda, T., Nakano, Y., Takahashi, M., Konno, N., Sakamoto, Y., Arashida, R., et al. (2015). Identification and enzymatic characterization of an endo-1,3$\beta$-glucanase from Euglena gracilis. Phytochemistry 116, 21-27. doi:10.1016/j. phytochem.2015.05.010

Van Maris, A. J. A., Abbott, D. A., Bellissimi, E., van den Brink, J., Kuyper, M., Luttik, M. A. H., et al. (2006). Alcoholic fermentation of carbon sources in biomass hydrolysates by Saccharomyces cerevisiae: current status. Antonie Van Leeuwenhoek 90, 391-418. doi:10.1007/s10482-006-9085-7

Van Zyl, W. H., Bloom, M., and Viktor, M. J. (2012). Engineering yeasts for raw starch conversion. Appl. Microbiol. Biotechnol. 95, 1377-1388. doi:10.1007/ s00253-012-4248-0

Viola, R., Nyvall, P., and Pedersen, M. (2001). The unique features of starch metabolism in red algae. Proc. Biol. Sci. 268, 1417-1422. doi:10.1098/rspb.2001.1644

Vreeland, V., and Kloareg, B. (2000). Cell wall biology in red algae: divide and conquer. J. Phycol. 36, 793-797. doi:10.1046/j.1529-8817.2000.36512.x

Wang, J., Kim, Y. M., Rhee, H. S., Lee, M. W., and Park, J. M. (2013). Bioethanol production from mannitol by a newly isolated bacterium, Enterobacter sp. JMP3. Bioresour. Technol. 135, 199-206. doi:10.1016/j.biortech.2012.10.012

Wang, Y., Xie, N., and Wang, W. (2009). Effects of algal concentration and initial density on the population growth of Diaphanosoma celebensis Stingelin (Crustacea, Cladocera). Chin. J. Oceanol. Limnol. 27, 480. doi:10.1007/ s00343-009-9267-z

Wargacki, A. J., Leonard, E., Win, M. N., Regitsky, D. D., Santos, C. N. S., Kim, P. B., et al. (2012). An engineered microbial platform for direct biofuel production from brown macroalgae. Science 335, 308-313. doi:10.1126/ science. 1214547

Wikfors, G. H., and Ohno, M. (2001). Impact of algal research in aquaculture. J. Phycol. 37, 968-974. doi:10.1046/j.1529-8817.2001.01136.x

Wolfe, A. J. (2015). Glycolysis for the microbiome generation. Microbiol. Spectr. 3(3). doi:10.1128/microbiolspec.MBP-0014-2014

Wong, T. Y., Preston, L. A., and Schiller, N. L. (2000). ALGINATE LYASE: review of major sources and enzyme characteristics, structure-function analysis, biological roles, and applications. Annu. Rev. Microbiol. 54, 289-340. doi:10.1146/ annurev.micro.54.1.289

Yanagisawa, M., Kawai, S., and Murata, K. (2013). Strategies for the production of high concentrations of bioethanol from seaweeds. Bioengineered 4, 224-235. doi:10.4161/bioe.23396

Yu, S., Blennow, A., Bojko, M., Madsen, F., Olsen, C. E., and Engelsen, S. B. (2002). Physico-chemical characterization of floridean starch of red algae. Starch Stärke 54, 66-74. doi:10.1002/1521-379X(200202)54:2<66:AID-STAR66>3.0. $\mathrm{CO} ; 2-\mathrm{B}$

Yun, E. J., Choi, I.-G., and Kim, K. H. (2015). Red macroalgae as a sustainable resource for bio-based products. Trends Biotechnol. 33, 247-249. doi:10.1016/j. tibtech.2015.02.006

Zamora, F. (2009). "Biochemistry of alcoholic fermentation," in Wine Chemistry and Biochemistry, eds M. V. Moreno-Arribas and M. C. Polo (New York: Springer), 3-26.

Zemke-White, W. L., and Ohno, M. (1999). World seaweed utilisation: an end-ofcentury summary. J. Appl. Phycol. 11, 369-376. doi:10.1023/A:1008197610793

Zheng, Y., Pan, Z., and Zhang, R. (2009). Overview of biomass pretreatment for cellulosic ethanol production. Int. J. Agric. Biol. Eng. 2, 51-68. doi:10.3965/ ijabe.v2i3.168

Conflict of Interest Statement: The authors declare that the research was conducted in the absence of any commercial or financial relationships that could be construed as a potential conflict of interest.

Copyright $\odot 2016 \mathrm{Al}$ Abdallah, Nixon and Fortwendel. This is an open-access article distributed under the terms of the Creative Commons Attribution License (CC BY). The use, distribution or reproduction in other forums is permitted, provided the original author(s) or licensor are credited and that the original publication in this journal is cited, in accordance with accepted academic practice. No use, distribution or reproduction is permitted which does not comply with these terms. 